\title{
Pengaruh Konsep Diri Dan Sikap Belajar Terhadap Kemampuan Berbahasa Inggris Siswa SMP Swasta
}

\author{
Noerlina Angraeni, M.Pd \\ Universitas MH Thamrin \\ nurlina_anggraeni@ymail.com
}

\begin{abstract}
ABSTRAK
Penelitian ini bertujuan untuk menunjukkan pengaruh konsep diri dan sikap belajar siswa secara bersama-sama terhadap kemapuan berbahasa Inggris. Metode penelitian yang digunakan adalah metode survey. Sampel yang diambil sebanyak 65 siswa dengan teknik acak sederhana. Penelitian ini dilaksanakan di SMP Swasta di Kecamatan Cilodong, Kota Depok. Pengumpulan data dilakukan penyebaran angket langsung kepada sampel. Analisis data menggunakan statistic deskriptif seperti mencari mean, median, standar deviasi dan statistik inferensial yaitu untuk mencari koefisien korelasi sederhana dan ganda yang dilanjtkan dengan uji signifikasi koefisien korelasi dengan uji t penelitian dini dilakukan pada bulan Januari. Hasil penelitian menunjukan : 1) Ada pengaruh positif konsep diri dan sikap belajar siswa terhadap kemampuan berbahasa Inggris dengan skor koefisien korelasi sederhana $r=0,767$ yang signifikan dan skor koefisien determinasi $r^{2}=0,589$ yang berarti bawha konstribusi konsep diri dan sikap belajar siswa terhadap kemampuan berbahasa Inggris sebesar $58,9 \%$. 2) Adanya pengaruh posotif konsep diri dan sikap belajar siswa terhadap kekampuan berbahasa Inggris dengan skor koefisien korelasi sederhana $r=0,677$ yang siginfikan dengan ${ }^{\mathrm{t}}$ hitung $(1,751)>{ }^{\mathrm{t}}$ tabel $(1,671)$ pada $\alpha=5 \%(0,05)$, dan skor koefisien korelasi $=0,589$, yang berarti bahwa kontribusi konsep diri terhadap kemampuan berbahasa Inggris sedang. 3) Terhadap pengaruh sikap belajar siswa terhadap kemampuan berbahasa Inggris dengan hitung $<{ }^{t}$ tabel atau $(2,731>1,671)$ pada $\alpha=5 \%(0,05)$. Hasil penelitian ini, terbukti bahwa konsep diri dan sikap belajar siswa sangat berpengaruh terhadap kemampuan siswa dalan berbahasa Inggris.
\end{abstract}

Kata Kunci : Konsep Diri, Sikap Belajar Siswa, Kemampuan Berbahasa Inggris.

\section{PENDAHULUAN}

Bahasa Inggris adalah bahasa yang berasal dari Inggris Raya. Bahasa internasional ini merupakan kombinasi dari beberapa bahasa lokal yang sering dipakai oleh oleh masyarakat Norwegia, Denmark dan Anglo-Saxon pada abad ke-6 sampai abad ke-10 dulu. Hingga ditaklukan Inggris oleh William the Conqueror pada tahun 1066, bahasa inggris pun mulai sangat intensif mempengaruhi bahasa Latin juga bahasa Perancis. Dari seluruhan kosakata bahasa inggris modern, diperkirakan $\pm 50 \%$ berasal dari bahasa Perancis dan Latin.

Saat ini, bahasa Inggris telah menjadi media komunikasi utama bagi masyarakat di berbagai Negara dunia, seperti Inggris, Amerika Serikat, Kanada, Australia, New Zealand, Afrika Selatan serta masih banyak lagi negara yang menjadikan bahasa Inggris sebagai media komunikasi utama Negara mereka. Sebagai bahasa yang paling banyak dipakai di berbagai dunia, bahasa Inggris sudah dianggap sebagau bahasa resmi untuk dipakai di dunia internasional. Bahasa yang juga hampir sama populernya seperti bahasa Inggis adalah bahsa mandarin.

Bahasa Inggris termasuk rumpun bahasa-bahasa Anglo-Fisia pada cabang barat bahasa-bahasa jerman dan merupkan sebuah bahasa subfamily dari bahasa-bahasa Indo-Eropa. Bahasa Inggris hamper mendekati bahasa Frisia, sedikit lebih luar dari bahasa Netherlandic (Belanda-Flemish) dan dialek Jerman tingkat rendah (Plattdeutsch) serta bahasa Jerman Modern tingkat tinggi.

Bahasa Inggris di Indonesia secara umum diajarkan sebagai bahasa asing. Istilah "bahasa asing" dalam bidang pengajaran bahasa berbeda dengan "bahasa kedua". Bahasa asing adalah bahasa yang 
tidak digunakan sebagai alat komunikasi di Negara tertentu dimana bahasa tersebut diajarkan. Sementara bahasa kedua adalah bahasa yang bukan bahasa utama namun menjadi salah satu bahasa yang digunakan secara umum di suatu Negara.

Di Indonesia, kebijakan pengajaran bahasa Inggris sebagai bahasa asing berubah seiring waktu dan pergantian kebijakan yang kebanyakan dipengaruhi ekonomi dan politik. Bahasa Inggris sudah menjadi salah satu mata pelajaran yang digunakan berbagai sekolah, mulai dari Taman Kanak-Kanak sampai Perguruan Tinggi. Dikurikulum bahasa Inggris merupakan pelajaran yang paling popular dan banyak diminati oleh para pelajar. Karena perkembangannya banyak orang Indonsia ingin bisa berbahasa Inggris dengan aktif sehingga banyak kita lita sekarang lembaga-lembaga yang membuka kursus bahasa Inggris.

Dalam hal ini peneliti melakukan penelitian "Pengaruh Konsep Diri Dan Sikap Belajar Terhadap Kemampuan Berbahasa Inggris Siswa SMP Swasta Di Kecamatan Cilodong, Kota Depok"

\section{METODE}

Penelitian ini dilaksanakan di SMP Swasta di Kecamatan Cilodong, Kota Depok. Dengan sasaran siswa, dipilihnya tempat tersebut diharapkan dapat menjamin permasalahan untuk mencapai tujuan penelitian. Adapun waktu penelitian dilaksanakan pada Bulan Januari. Pengambilan sampel dilakukan secara random sampling (Suharsimi Arikunto, 1977:120), mengemukakan bahwa sekedar ancer-ancer, maka apabila subjek kurang dari 100, maka lebih baik diambil semua, sehingga penelitiannya merupakan penelitian populasi”. Pengambikan sampel dilakukan di siswa SMP Budi Insani Cendikia yang berlokasi di Jalan Boulevard, SMP Intergral Hidayatullah Jalan Raya Kalimulya dan SMPIT Asshof Jalan raya Kalimulya Kebon Duren, yang berjumlah 65. Penelitian ini menggunakan metode survei dengan pendekatan kuantitatif karena data penelitian yang diperoleh menggunakan angkaangka dan analisisnya menggunakan statistik. Pada pendekatan kuantitatif yang digunakan untuk penelitian adan populasi dan sampel, teknik pengambilan sampel pada umumnya dilakukan secara random, pengumpulan data menggunakan instrumen penelitian, analisis dan data bersifat kuantitatif atau statistik yang bertujuan untuk menguji hipotesis yang telah ditetapkan.

Penelitian deskriptif dengan pendekatan kuantitatif atau bisa disebut deskriptif kuantitatif, karena peneleti menganalisi dan mengklasifikasikan dengan menggunakan angket atau mengungkapkan suatu fenomena dengan menggunakan dasar perhitungan. Seperti yang diungkapkan oleh Sugiyono (2006:10)"Penelitian deskriptif kuantitatif adalah penelitian yang dimaksud memperoleh data yang berbentuk angka atau data kuatitaif yang diangkakan"

Dalam penelitian ini, untuk mewujudkan arah pemecahan dan penganalisisan masalah yang dihadapi, maka terlebih dahulu perlu dikemukanan gambaran berupa kerangkan pemikian sebagai berikut:

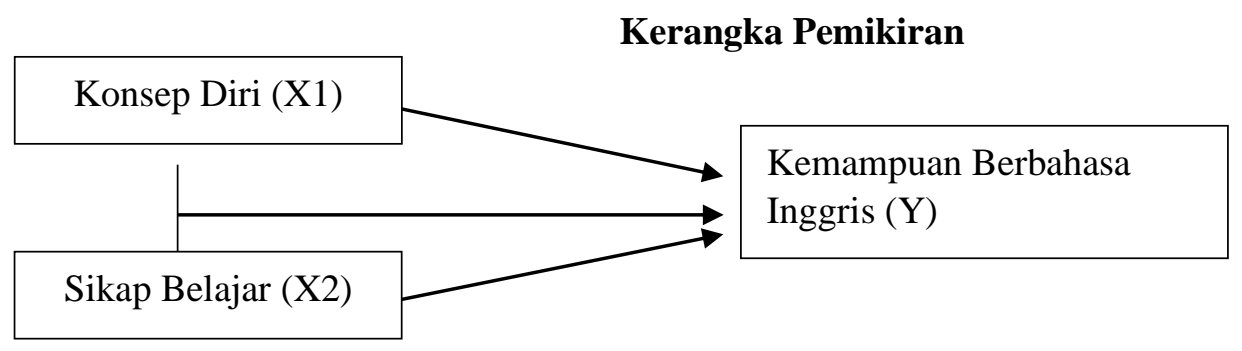

Keterangan:

Uraian kerangka di atas dapat dijelaskan bahwa antara konsep diri (X1), sikap belajar (X2) dan kemampuan menulis argumentasi (Y) mempunyai hubungan yang tidak dapat dipisahkan, artinya apabila proses pembelajaran didukung dengan pemahaman, mutu dan profesionalitas, maka pada akhirnya akan diperoleh kemampuan berbahasa inggris yang optimal. 


\section{HASIL DAN PEMBAHASAN}

Analisis deskriptif data ini dimaksudkan untuk memberikan gambaran terhadap kondisi masingmasing variabel yang diteliti, yaitu variabel bebas (konsep diri dan sikap belajar) dan variabel terikat. Dalam pengumpulan data ini peneliti menggunakan angket dan nilai rapot sebanyak 65 orang.

\section{Uji Hipotesisi Penelitian}

Pengujian hipotesisi dilakukan dengan menggunakan teknik analisis regresi dan kolerasi ganda. Berdasakan hasil perhitungan dengan program SPSS versi 22.0 diperoleh sebagai berikut:

\section{Tabel 1}

Model Summary

\section{Koefisien Korelasi dan Koefisien Determinasi}

\begin{tabular}{|l|l|l|l|l|}
\hline Model & $\mathrm{R}$ & R Square & $\begin{array}{l}\text { Adjusted R } \\
\text { Square }\end{array}$ & $\begin{array}{l}\text { Std. Error of } \\
\text { the Estimate }\end{array}$ \\
\hline 1 &, 767 &, 589 &, 576 & 5,03342 \\
\hline
\end{tabular}

a. Predicators: (Constant), sikap belajar, konsep diri

b. Dependent variabel: nilai bahasa inggris

Tabel 2

Signifikansi Koefisiensi Regresi

Anova $^{a}$

\begin{tabular}{|l|l|l|l|l|l|}
\hline Model & $\begin{array}{l}\text { Sum of } \\
\text { Squares }\end{array}$ & Df & Mean Square & $\mathrm{F}^{\mathrm{o}}$ & Sig. \\
\hline $\begin{array}{l}\text { 1 Regression } \\
\text { Residual }\end{array}$ & 2249,149 & 2 & 1124,574 & 44,388 &, $000^{\mathrm{b}}$ \\
Total & 1570,790 & 62 & 25,335 & & \\
\hline
\end{tabular}

a. Dependent variabel: nilai bahasa inggris

b. Predicators: (Constant), sikap belajar, konsep diri

Tabel 3

Coefficients $^{\mathrm{a}}$

Signifikansi dan Linearitas Konsep Diri dan Sikap Belajar

\begin{tabular}{|l|l|l|l|l|l|}
\hline & \multicolumn{2}{|l|}{$\begin{array}{l}\text { Unstandardized } \\
\text { Coefficients }\end{array}$} & $\begin{array}{l}\text { Standardized } \\
\text { Coefficients }\end{array}$ & & \\
\cline { 2 - 4 } Model & B & Std. Erros & Beta & T & Sig. \\
\hline 1 (Constant) & 12,716 & 7,260 & & 1,752 &, 085 \\
Konsep Diri &, 367 &, 210 &, 308 & 1,751 &, 085 \\
Sikap belajar &, 530 &, 194 &, 481 & 1,731 &, 008 \\
\hline
\end{tabular}

a. Dependent variabel : nilai bahasa Inggris

Hipotesis Pertama : Terdapat pengaruh konsep diri dan sikap belajar secara bersama-sama terhadap kemapuan berbahasa Inggris.

Berdasarkan tabel 1 tentang koefisien korelasi dan koefisien determinasi diperoleh hasil koefisien kolerasi sebesar 0,767. Hal ini menunjukkan bahwa terdapat pengaruh yang sedang konsep diri dan sikap belajar secara bersama-sama terhadap kemampuan berhasa Inggris. Koefisien determinasi yang dihasilkan sebesar 0,589 atau 58,9\% dapat diartikan bahwa kemampuan berbahasa Inggris dipengaruhi oleh konsep diri dan sikap belajar sebesar $88,9 \%$, sedangkan $41,1 \%$ dipengaruhi oleh faktor lain.

Berdasarkan tabel 3, diperoleh sebuah persamaan regresi ganda $\hat{Y}=12,716+0,367 X_{1}+0,53 X_{2}$, persamaan tersebut dapat diartikan sebagai berikut: Konstanta sebesar 12,716 menunjukan bahwa dalam keadaan variabel bebas, yaitu konsep diri dan sikap belajar tidak mengalami perubahan atau konstan (sama dengan nol) maka kemampuan berbahasa Inggris sebesar 12,716. Koefisien regresi 0,367 menunjukkan bahwa dalam keadaan variabel bebas, yaitu konsep diri mengalami kenaikan sebesar satu satuan dan sikap belajar tidak mengalami kenaikan atau konstan maka kemampuan 
berbahasa Inggris mengalami kenaikan sebesar 13,083. Koefisien regresi 0,53 menunjukkan bahwa dalam keadaan variabel bebas, yaitu sikap belajar mengalami penurudan sebesar satu satuan dan konsep diri tidak mengalami kenaikan atau konstan maka kemampuan berbahasa Inggris mengalami kenaikan sebesar 13,246.

Pengujian signifikan regresi menggunakan tabel coefficient ${ }^{\mathrm{a}}$ digunakan untuk mengetahui seberapa besar signifikan atau keberartian koefisien a pada persamaan regresi pengaruh konsep diri dan sikap belajar terhadap kemampuan berbahasa Inggris, dapat dilihat nilai koefisien sign sebesar 0,000, dimana nilai sign tersebut $<0,05$ sehingga dapat disimpulkan bahwa persamaan regresi konsep diri dan sikap belajar terhadap kemampuan berbahasa Inggris signifikan.

Setelah diperoleh persamaan regresi sebaimana tercantum diatas, langkah selanjutnya menguji keberartian dan kelinearan dari persamaan regresi tersebut. Ujia keberartian ini perlu dilakukan untuk menyakinkan pengambilan kesimpulan. Untuk itu keberartian menggunakan uji $\mathrm{F}$, dimana rumus hipotesis yang diajukan adalah :

$\mathrm{H}_{0} \quad$ : Tidak terdapat pengaruh sigifikan konsep diri dan sikap belajar secara bersama-sama terhadao kemampuan berbahasa Inggris.

$\mathrm{H}_{1} \quad$ : Terdapat pengaruh signifikan konsep diri dan sikap belajar secara bersama-sama terhadap kemampuan berbahasa Inggris.

Kriteria pengujian:

Terima $\mathrm{H}_{1}$; jika $\mathrm{F}_{\text {hitung }}>\mathrm{F}_{\text {tabel }}$

Tolak $\mathrm{H}_{1}$; jika $\mathrm{F}_{\text {hitung }}<\mathrm{F}_{\text {tabel }}$

Berdasarkan tabel 2 anova di atas, diperoleh $F_{\text {hitung }}=44,388$ selanjutnya nilai $F_{\text {tabel }}$ dengan menggunakan $\alpha=5 \%(0,05)$, dk pembilang $=2$ dan dk penyebut $=65$ dimana $\mathrm{n}$ adalah banyak data dan $\mathrm{k}$ jumlah variabel independen. Hasil $\mathrm{F}_{\text {tabel }}$ diperoleh 3,14, karena $\mathrm{F}_{\text {hitung }}>\mathrm{F}_{\text {tabel }}$ atau $(44,388>$ 3,14), maka disimpulkan $\mathrm{H}_{1}$ diterima artinya terdapat pengaruh konsep diri dan sikap belajar terhadap kemampuan berbahasa Inggris.

\section{Hipotesis Kedua: Pengaruh Konsep Diri Terhadap Kemampuan Berbahasa Inggris}

$$
\begin{array}{lll}
\text { Hipotesis yang akan diuji } & \mathrm{H}_{0} & : \beta 1=0 \\
& \mathrm{H}_{1} & : \beta 1 \neq 0
\end{array}
$$

$\mathrm{H}_{0} \quad=$ Terdapat pengaruh konsep diri kemampuan berbahasa Inggris.

$\mathrm{H}_{1} \quad$ = Tidak terdapat pengaruh konsep diri terhadap kemampuan berbahasa Inggris.

Berdasarkan tabel 3, diperoleh sebuah persamaan regresi sederhana $\hat{Y}=12,716+0,367 \mathrm{X}_{1}$, yang berarti koefisien regresi 0,367 menunjukkan bahwa dalam keadaan variabel bebas, yaitu konsep diri mengalami kenaikan sebesar satu satuan maka kemampuan berbahasa Inggris mengalami kenaikan sebesar 13,083.

Pengujian signifikan regresi menggunakan tabel coefficient ${ }^{\mathrm{a}}$ digunakan untuk mengetahui seberapa besar signifikan atau keberartian koefisien a pada persamaan regresi pengaruh konsep diri dan terhadap kemampuan berbahasa Inggris. Rumusan hipotesis yang diajukan adalah:

$\mathrm{H}_{0} \quad$ : Koefisien regresi tidak signifikan

$\mathrm{H}_{1} \quad$ : Koefisien regresi signifikan

Kriteria pengujian:

Terima $\mathrm{H}_{0}$; jika $\mathrm{t}_{\text {hitung }}<\mathrm{t}_{\text {tabel }}$ dengan $\mathrm{dk}=\mathrm{n}-2, \alpha=5 \%$

Terima $\mathrm{H}_{0}$; jika $\mathrm{t}_{\text {hitung }}>\mathrm{t}_{\text {tabel }}$ dengan $\mathrm{dk}=\mathrm{n}-2, \alpha=5 \%$

Keputusan dari tabel diatas diperoleh $t_{\text {hitung }}=1,751$ sedangakan $t_{\text {tabel }}=1,671(\quad \alpha=5 \%, \quad d k=63)$. Karena $t_{\text {hitung }}>\mathrm{t}_{\text {tabel }}$ atau $(1,751>1,671)$, disimpulkan tolak $\mathrm{H}_{0}$, artinya koefisien a pada persamaan regresi signifikan, sehingga dapat dikatakan bahwa konsep diri mempengaruhi kemampuan berbahasa Inggris.

\section{Hipotes Ketiga: Pengaruh Sikap Belajar Terhadap Kemampuan Berbahasa Inggris.}

Hipotesis yang akan diuji $\quad \mathrm{H}_{0} \quad: \beta 2=0$

$\mathrm{H}_{1} \quad: \beta 2 \neq 0$

$\mathrm{H}_{0} \quad=$ Terdapat pengaruh sikap belajar terhadap kemampuan berbahasa Inggris.

$\mathrm{H}_{1} \quad=$ Tidak terdapat pengaruh sikap belajar terhadap kemampuan berbahasa Inggris.

Berdasarkan tabel 3, diperoleh sebuah persamaan regresi sederhana $\hat{Y}=12,716+0,53 \mathrm{X}_{2}$, yang berarti koefisien regresi 0,53 menunjukkan bahwa dalam keadaan variabel bebas, yaitu sikap belajar 
mengalami kenaikan sebesar satu satuan. Maka, kemampuan berbahasa Inggris mengalami kenaikan sebesar 13,246.

Pengujian signifikan regresi menggunakan tabel coefficient ${ }^{\mathrm{a}}$ digunakan untuk mengetahui seberapa besar signifikan atau keberartian koefisien a pada persamaan regresi pengaruh sikap belajar terhadap kemampuan berbahasa Inggris. Rumusan hipotesis yang diajukan adalah:

$\mathrm{H}_{0}$ : Koefisien regresi tidak signifikan

$\mathrm{H}_{1}$ : Koefisien regresi signifikan

Kriteria pengujian:

Terima $\mathrm{H}_{0}$; jika $\mathrm{t}_{\text {hitung }}<\mathrm{t}_{\text {tabel }}$ dengan $\mathrm{dk}=\mathrm{n}-2, \alpha=5 \%$

Terima $\mathrm{H}_{0}$; jika $\mathrm{t}_{\text {hitung }}>\mathrm{t}_{\text {tabel }}$ dengan $\mathrm{dk}=\mathrm{n}-2, \alpha=5 \%$

Keputusan dari tabel diatas diperoleh $t_{\text {hitung }}=2,731$ sedangakan $t_{\text {tabel }}=1,671(\quad \alpha=5 \%, \quad d k=63)$, karena $t_{\text {hitung }}>t_{\text {tabel }}$ atau $(2,731>1,671)$, maka disimpulkan terima $H_{1}$, artinya koefisien a pada persamaan regresi signifikan sehingga dapat dikatakan bahwa sikap belajar signifikan mempengaruhi kemampuan berbahasa Inggris.

\section{Pembahasan Hasil Penelitian}

Penelitian ini bertujuan untuk mengetahui hubungan antara konsep diri dan sikap belajar siswa secara bersama-sama dengan kemampuan berbahasa Inggris siswa.

Pengaruh Konsep Diri dan Sikap Belajar Terhadap Kemampuan Berbahasa Inggris.

Berdasarkan hasil perhitungan diperoleh $\mathrm{F}_{\text {hitung }}>\mathrm{F}_{\text {tabel }}$ atau $(44,388>3,14)$ dapat dinyatakan bahwa terdapat pengaruh konsep diri dan sikap belajar secara bersama-sama terhadap kemapuan berbahsa Inggris. Konsep diri merupakan gambar yang dimiliki seseorang tentang dirinya, yang dibentuk melalui pengalaman-pengalaman yang diperoleh dari interaksi dengan lingkungan. Konsep diri bukan merupakan faktor bawaan, melainkan berkembang dari pengalaman yang terus menerus dan terdiferensi. Dasar konsep diri individu pada saat-saat dini kehidupan anak dan menjadi dasar yang mempengaruhi tingkah lakunya dikemudian hari. Jika kita memiliki sikap pada suatu obyek, kita tidak cuma mengalaminya, tetapi mengalaminya sebagai sesuatu yang hingga batas tertentu diinginkan atau lebih baik, atau lebih buruk. Dengan konsep diri yang tinggi, siswa akan mempunyai penguasaan kata-kata yang banyak yang diperolehnya dari informasi-informasi yang dibacanya melalui berbagai sumber bacaan. Hal ini akan membuatnya memiliki pandangan dan wawasan yang luas. Selanjutnya, mereka pun mampu mengutarakan maksudnya melalui aktivitas berbicara, dari sinilah peniliti dapat mengukur sejauh mana keterampilan berbicara siswa yang bersangkutan. Penelitia berkesimpulan bahwa konsep dasar diri dan sikap belajar mempunyai pengaruh yang positif dan signifikan secara bersama-sama terhadap kemampuan berbahasa Inggris.

Pengaruh Konsep Diri Terhadap Kemampuan Berbahasa Inggris.

Hasil perhitungan yang menyatakan bahwa $t_{\text {hitung }}<t_{\text {tabel }}$ atau $(1,751>1,671)$ akan terjabarkan bahwa pengaruh yang signifikan antara konsep diri dengan kemampuan berbahasa Inggris. Siswa yang mendapatkan konsep diri baik akan dengan mudah mempratekkan bahasa Inggris yang sesuai dengan materi pembelajaran. Berbeda dengan siswa yang mendapatkan konsep diri kurang baik, siswa akan merasa kesulitan dalam mempraktekan bahasa Inggris sesuai dengan materi pembelajaran. Berdasarkan kerangka berpikir diatas, patut diduga bahwa konsep diri baik memberikan pengaruh yang lebih unggul dibandingkan konsep diri kurang baik terhadap kemampuan berbahasa Inggris siswa.

Pengaruh Sikap Belajar Terhadap Kemampuan Berbahasa Inggris

Hasil perhitungan dapat dikatakan bahwa terdapat pengaruh sikap belajar terhadap kemampuan berbahasa Inggris. Hasil perhitung yang menyatakan bahasa $t_{\text {hitung }}<\mathrm{t}_{\text {tabel }}$ atau $(2,731>1,671)$, bahwa terdapat pengaruh yang signifikan antara sikap belajar dan kemampuan berbahasa Inggris. Ketidak mampuan siswa dalam berbahasa Inggris merupakan akibat dari kurangnya sikap belajar. Hal tersebut menjadikan siswa merasa bosan dan tidak tertarik dengan pembelajaran, meski kompetensinya berbeda dapat menyebabkan menurunya kemampuan siswa dalam pembelajaran. Kesimpulanya diduga bahawa siswa akan mampu berbahasa Inggris jika seorang siswa mempunyai sikap belajar tinggi, berbeda dengan seorang siswa yang mempunyai sikap belajar rendah.

Penelitian ini telah diusahakan dan dikontrol agar hasil yang diperoleh sesuai dengan tujuan yang ingin dicapai. Namun, peneliti menyadari sepenuhnya bahwa dalam penelitian ini masih banyak 
terdapat kekurangan dan kelemahan dari proses awal sampai hasil penelitian diperoleh, yang dianggap sebagai suatu keterbatasan penelitian. Keterbatasan dalam penelitian ini, antara lain keterbatasan pengetahuan dan pengalaman sehinga terjadi kekurang tepatan, mulai dari penentuan populasi, penarikan sampel, penyusunan dan uji coba instrument, sampai proses pengolahan dan penarikan kesimpulan.

\section{KESIMPULAN DAN REKOMENDASI}

Berdasarkan hasil pengujian hipotesis dan pembahasan hasil penelitian dapat diambil kesimpulan dan rekomendari yang bersifat sintetik dan sistemik. Kesimpulan yang rumusanya bersifat umum yang merupakan dari bagi pengkajian selanjutnya. Beberapa kesimpulan penelitian dapat disajikan sebagai berikut:

1. Terhadap pengaruh yang signifikan secara bersama-sama konsep diri dan sikap belajar terhadap kemampuan berbahasa Inggris. Hal tersebut dibuktikan dari hasil perhitungan yang menyatakan $\mathrm{F}_{\text {hitung }}>\mathrm{F}_{\text {tabel }}$ atau $(44,388>3,14)$ dan Sig $0,000<0,05$.

2. Terdapat pengaruh yang signifikan konsep diri terhadap kemampuan berbahasa Inggris siswa kelas VII SMP Swasta di Kecamatan Cilodong, Kota Depok. Hal tersebut dibuktikan dengan $t_{\text {hitung }}$ $>t_{\text {tabel }}$ atau $(1,751>1,671)$ dan Sig $0,000>0,05$.

3. Terdahap pengaruh yang signifikan sikap belajar terhadap kemampuan berbahasa Inggris siswa kelas VII SMP Swasta di Kecamatan Cilodong, Kota Depok. Hal tersebut dibuktikan dengan thitung $>t_{\text {tabel }}$ atau $(2,731>1,671)$ dan Sig $0,000<0,05$.

Peneliti ingin memberikan saran-saran yang mudah-mudahan dapat bermanfaat bagi khalayak banyak, yaitu :

1. Kepada Kepala Sekolah sebagai leader keberhasilan institusional sekolah, hendaknya memperhatikan secara serius konsep diri, sikap belajar dan kemampuan berbahasa Inggris siswa.

2. Kepada seluruh pegawai dan semua pihak yang terkait untuk terus mengupayakan kualitas proses pendidikan dengan mengoptimalkan berbagai elemen terkait sumber daya manusia maupun sarana prasarana yang diperlukan guna menunjang proses belajar mengajar yang berkualitas.

\section{Referensi}

Arikunto, Suharsimi. 1997. Prosedur Penelitian Suatu Pendekatan Praktek. Jakarta : Rineka Cipta. Sugiyono. 2006. Metode Penelitian Pendidikan Pendekatan Kuantitatif, Kualitatif, dan R\&D (Mixed. Methods). Bandung : Alfabeta

Putri, N. K. N., Danial, M., \& Arsyad, N. (2018). Pengaruh sikap, konsep diri, dan kesadaran metakognitif terhadap hasil belajar kimia peserta didik kelas XI MIA SMAN di kecamatan Ujung bulu kabupaten Bulukumba. Chemistry Education Review (CER), (1), 73-89.

Rosa, N. M. (2015). Pengaruh sikap pada mata pelajaran kimia dan konsep diri terhadap prestasi belajar kimia. Formatif: Jurnal Ilmiah Pendidikan MIPA, 2(3).

Fajriyah, L., Nugraha, Y., Akbar, P., \& Bernard, M. (2019). Pengaruh Kemandirian Belajar Siswa SMP Terhadap Kemampuan Penalaran Matematis. Journal on Education, 1(2), 288-296.

ASTAWA, I. M. W., Sadia, I. W., \& Suastra, I. W. (2015). Pengaruh model pembelajaran berbasis proyek terhadap sikap ilmiah dan konsep diri siswa smp. Jurnal Pendidikan dan Pembelajaran IPA Indonesia, 5(1). 